\title{
A ciência contra a metafísica: Nietzsche e o filosofar histórico em Humano, demasiado humano I*
}

\author{
Neomar Sandro Mignoni**
}

\begin{abstract}
Resumo: Com Humano, demasiado humano I, Nietzsche estabeleceu sua definitiva ruptura com a metafísica de Schopenhauer e a arte de Wagner, ao mesmo tempo que concedeu à ciência maior destaque para que, juntamente com o filosofar histórico, pudesse lhe servir de principal aliada no combate aos erros e excessos da metafísica, da religião e da arte, sobretudo a romântica. $\mathrm{O}$ presente estudo pretende investigar como Nietzsche relaciona algumas características que vê na ciência de sua época com sua proposta de filosofia histórica, a qual se contrapõe à metafísica tradicional.
\end{abstract}

Palavras-chave: Nietzsche, ciência, história, metafísica.

* O presente trabalho foi realizado com apoio da Coordenação de Aperfeiçoamento de Pessoal de Nível Superior - Brasil (CAPES) - código de Financiamento 001.

** Doutorando em Filosofia Moderna e Contemporânea na Universidade Estadual do Oeste do Paraná, Toledo, PR, Brasil.

ORCID https://orcid.org/0000-0003-2181-7688

Correio eletrônico: neomarmignoni@hotmail.com

74 Cad. Nietzsche, Guarulhos/Porto Seguro, v.40, n.2, p. 74-97, maio/agosto, 2019. 
Ao longo da obra nietzschiana, o discurso sobre a ciência perpassa quase que invariavelmente todos os seus escritos, sejam eles as obras publicadas, os fragmentos póstumos ou até mesmo suas cartas. Ainda que tal assunto seja bastante amplo e se apresente sob diversas facetas, perfazendo o caminho do desenvolvimento desses escritos, é possível encontrar elementos essenciais à compreensão dessa noção. Embora possua relevante importância no decorrer de outras obras do filósofo, nos ocuparemos aqui apenas de Humano, demasiado humano I, uma vez que essa é, sem dúvida, seja pelo conteúdo, seja pela ordem cronológica de sua escrita, a primeira obra publicada em que a ciência adquire primazia dentre as obras do filósofo. Nesse sentido, o presente estudo dedica-se a investigar as características da concepção de ciência em sua relação com o filosofar histórico conforme o proposto por Nietzsche ao longo da obra na contraposição ao filosofar metafísico.

Humano, demasiado humano é também a primeira grande obra propriamente nietzschiana, em que pela primeira vez o filósofo traçou "os contornos de seu próprio pensamento", na qual expressou as "mais íntimas impressões sobre os homens e as coisas" (Nietzsche, 1995, III, p. 676), e se distancia das ilusões metafísico-artísticas para enfim buscar a liberdade do espírito, buscar a si próprio. ${ }^{1}$ No Ecce Homo, na seção dedicada ao Humano, demasiado humano, o filósofo a descreve enquanto o "monumento de uma crise", um livro que se proclama para espíritos livres, em que "cada frase ali expressa vitória". Nela se expressa "um brusco fim a todo 'embuste superior', idealismo', 'sentimento belo' e outras feminilidades de que fora contagiado" (EH/EH, Humano, demasiado humano, 5). Em resumo, ela constituiu "um grande livramento" [einer großen

1 No fragmento póstumo 5 [190] de 1875 (KSA 8.94), escrito antes mesmo do festival de Bayreuth e dos manuscritos de Humano, demasiado humano I, o filósofo já declarara: "Não deverá passar muito tempo e deverei manifestar opiniões que são consideradas ignominiosas (schmählich) para aquele que as nutre. Também os amigos e conhecidos se tornarão tímidos e assustados. Também por este fogo devo passar. Eu pertenço a mim mesmo cada vez mais". 
Mignoni, N. S.

Loslösung] de tudo aquilo que não era próprio de sua natureza, como ele mesmo descreve no prefácio à obra, escrito em 1886 (cf. MA I/ HH I, Prefácio, 3, KSA 2.15). ${ }^{2}$

A forma aforismática de Humano, demasiado humano também revela que tal obra constitui uma grande novidade em relação aos escritos precedentes de Nietzsche. Não apenas o conteúdo é diferente, mas também seu estilo, de modo que é bastante perceptível, desde a primeira leitura, uma espontânea mudança de tonalidade no discurso do filósofo em relação aos escritos anteriores. Distintamente de $O$ Nascimento da tragédia (1872), por exemplo, em que o filósofo propunha uma reforma da cultura alemã fundamentada na metafísica da arte e no renascimento do mito trágico a partir dos elementos de Schopenhauer e Wagner, no Humano, demasiado humano, acompanhamos a busca por uma filosofia própria cada vez mais distante da metafísica schopenhaueriana e de suas antigas influências, possibilitando, assim, o desenvolvimento de uma originalidade de pensamento cujo protagonismo passa a ser exercido agora pela ciência.

Nesse sentido, como bem assinalou Montinari ${ }^{3}$ no aparato crítico publicado junto à versão para o italiano da obra e de seus referidos fragmentos póstumos, seria precipitado e até incorreto afirmar que as mudanças ocorridas na vida do filósofo que possibilitaram a elaboração de Humano, demasiado humano sejam fruto do distanciamento de Wagner e Schopenhauer. Humano, demasiado humano não é uma obra elaborada em direta contraposição às influências de Wagner e Schopenhauer, mas, antes, o resultado de um processo de amadurecimento daquelas ideias que o filósofo vinha elaborando e desenvolvendo antes mesmo de sua declarada ruptura com Wagner e Schopenhauer e que, por algum motivo permaneciam desconhecidas

2 Em um fragmento póstumo de 1876, escrito durante sua viagem a Sorrento, o filósofo escreveu também: "Aos leitores de meus escritos anteriores declaro expressamente que abandonei as posições metafísico-estéticas essencialmente ali dominantes: elas são agradáveis, porém, insustentáveis" (Nachlass/FP 23[159], KSA 8.463).

3 Montinari, 1965, p. 476.

$76 \mid$ Cad. Nietzsche, Guarulhos/Porto Seguro, v.40, n.2, p. 74-97, maio/agosto, 2019. 
do grande público. ${ }^{4}$ Não encontramos aqui uma atitude renegada do filósofo em relação a Wagner, o qual, diga-se de passagem, sequer é citado na obra, mas antes a busca pela própria originalidade de pensamento. Talvez a característica mais honesta que se possa atribuir a essa obra seja a de que ela marca a passagem do filósofo a uma fase em que essa originalidade ainda não se distingue totalmente da dependência, embora já se vislumbre uma conquista de autonomia bem como a resolução dos conflitos interiores através do aprofundamento filosófico. Isso se reflete também na independência da linguagem adotada e no modo com que tudo aquilo que anteriormente parecia contraditório passa agora a ser incorporado, tematizado e aprofundado.

Quanto a essas possíveis contradições ou mudança de postura, Montinari ${ }^{5}$ afirma ainda que, para além das manifestações antinômicas, contraditórias e heterogêneas presentes no pensamento de Nietzsche, existe uma concordância, um fio condutor que se revela continuamente e de tal modo que os contrastes mais estridentes terminam por ordenarse como "expressões graduais de uma personalidade unitária, cuja riqueza, todavia, não poderia vir à luz de outro modo". Dentre essas diferenças, a que mais se evidencia entre o contexto de Humano, demasiado humano e os escritos precedentes refere-se à ciência e à arte. Sobre esse aspecto é bastante visível que, enquanto no período do Nascimento da tragédia e das Extemporâneas a arte assume maior proeminência, no período de Humano, demasiado humano, esse

\footnotetext{
4 Acerca de sua ruptura com Wagner e a obra em questão, no Ecce Homo, na seção dedicada ao Humano, demasiado humano, o filósofo também declarou: "O que em mim então se decidiu não era uma ruptura com Wagner - eu percebi um total desvio de meu instinto, do qual um desacerto particular, fosse ele Wagner ou a cátedra de Basiléia, era apenas um sinal. Uma impaciência comigo mesmo me tomou; vi que era hora de refletir, retornar a mim. De súbito ficou terrivelmente claro quanto tempo já fora desperdiçado - quão inútil e arbitrariamente toda a minha existência de filólogo destoava de minha tarefa. Envergonhei-me dessa falsa modéstia... Dez anos atrás de mim, durante os quais a alimentação de meu espírito havia literalmente cessado, em que eu nada de útil havia mais aprendido, em que havia esquecido absurdamente tanto, debruçado sobre a tralha de erudição empoeirada. (...) Tive pena ao me ver tão magro, tão esquálido: as realidades faltavam inteiramente em meu saber, e as ‘idealidades' para que diabos serviam!" (EH/EH, Humano, Demasiado Humano, 3, KSA 6.324-5).

5 Montinari, 1965, p. 477.
}

Cad. Nietzsche, Guarulhos/Porto Seguro, v.40, n.2, p. 74-97, maio/agosto, 2019. $\mid 77$ 
Mignoni, N. S.

destaque pertence à ciência. Levando-se em conta os póstumos e demais escritos do período e anteriores ao Nascimento da tragédia, percebemos que a ciência sempre assumiu importância central no pensamento do filósofo não havendo, portanto, uma mudança de postura tampouco uma retratação, até porque, como a própria obra nos mostra, "o homem científico é a continuação do homem artístico" (MA I/HH I 222, KSA 2.186).

Desde as primeiras páginas de Humano, demasiado humano Nietzsche contrapõe a filosofia histórica à filosofia metafísica. Segundo ele, em quase todos pontos, os problemas filosóficos continuariam sendo formulados como há dois mil anos. "Como pode algo originarse de seu oposto, por exemplo, o racional do irracional, o sensível do morto, o lógico do ilógico, a contemplação desinteressada do desejo cobiçoso, a vida para o próximo do egoísmo, a verdade dos erros?" (MA I/HH I 1, KSA 2.23), questiona o filósofo. Até o momento, a filosofia metafísica resolveu esse problema negando a gênese de um a partir do outro e concebendo uma origem miraculosa às coisas de mais alto valor. Tal origem estaria fundada no próprio âmago, na própria essência da coisa em si, razão pela qual a metafísica não passa de mera ilusão, uma imensa ficção que o homem inventa para si mesmo a fim de dar significado infinito à própria existência. ${ }^{6} \mathrm{~A}$ crença na liberdade da vontade, como também a crença na substância incondicionada, constitui um erro original e antigo de tudo o que é orgânico. Por conta disso, à medida que se ocupou majoritariamente

6 Em Para além de bem e mal (§2) o filósofo retoma essa ideia, e de modo mais claro escreve: "Nossas mentes rechaçam a ideia do nascimento de uma coisa que pode nascer de uma contrária, por exemplo: a verdade do erro; a vontade do verdadeiro da vontade do erro; o ato desinteressado do egoísmo ou a contemplação pura do sábio, da cobiça. Tal origem parece impossível: pensar nisso parece próprio de loucos. As realidades mais sublimes devem ter outra origem, que lhes seja peculiar. Não pode ser sua mãe esse mundo efêmero, falaz, ilusório e miserável, esta emaranhada cadeia de ilusões, desejos e frustrações. No seio do ser, no qual não morrerá nunca, um deus oculto, na 'coisa-em-si' é onde deve se abrigar seu princípio, ali e em nenhuma outra parte. Este é o preconceito característico dos metafísicos de todos os tempos, este gênero de apreciação se encontra na base de todos os seus procedimentos lógicos. A partir desta 'crença' esforçam-se em alcançar um 'saber', criam a coisa que, afinal, será pomposamente batizada com o nome de "verdade”" (JGB/BM 2, KSA 5.16).

78 Cad. Nietzsche, Guarulhos/Porto Seguro, v.40, n.2, p. 74-97, maio/agosto, 2019. 
A ciência contra a metafísica: Nietzsche e o filosofar histórico...

com a substância e a liberdade do querer, toda a metafísica acabou por perpetuar esse erro original, motivo pelo qual o filósofo a designa como a "a ciência que trata dos erros fundamentais do homem, mas como se fossem verdades fundamentais" (MA I/HH I 18, KSA 2.40).

No entender de Nietzsche, a origem da metafísica está na má interpretação dos sonhos, pois, segundo ele, sem o sonho não haveria motivo algum para a divisão do mundo. Segundo ele, "nas épocas de cultura tosca e primordial o homem acreditava conhecer no sonho um segundo mundo real" o que configuraria, portanto, a origem de toda a metafísica. Nesse sentido, a própria "decomposição em corpo e alma se relaciona à antiquíssima concepção de sonho, e igualmente a suposição de um simulacro corporal da alma", o que fundamentaria, contudo, "a origem de toda crença nos espíritos e também, provavelmente, da crença nos deuses" (MA I/HH I 5, KSA 2.27). Por conta disso, a tarefa essencial da metafísica consiste em oferecer uma explicação "pneumática" (espiritual) ao livro da natureza, tal qual a Igreja e os eruditos procediam em relação à bíblia: "É preciso grande inteligência para aplicar à natureza o mesmo tipo de rigorosa arte interpretativa que os filólogos de hoje criaram para todos os livros: com a intenção de meramente compreender o que quer dizer o texto, e não de farejar ou mesmo pressupor, um duplo sentido" (MA I/HH I 8, KSA 2.28-9).

Sob essa perspectiva, Nietzsche afirma que os filósofos acabaram por colocar-se frente à vida e à experiência, frente àquilo que denominam por fenômeno, como se estivessem frente a uma pintura que foi desenrolada de uma vez por todas e que a cada vez mostra invariavelmente o mesmo evento. Tal evento deveria ser "interpretado de modo correto, para que se tire uma conclusão sobre o ser que produziu a pintura: isto é, sobre a coisa-em-si, que sempre costuma ser vista como a razão suficiente do mundo do fenômeno" (MA I/HH I 16, KSA 2.36). Por outro lado, depois que os lógicos mais rigorosos estabeleceram o conceito do metafísico enquanto 
Mignoni, N. S.

incondicionado acabaram por contestar qualquer relação entre $o$ mundo metafísico e o mundo por nós conhecido. Por conta disso, a coisa-em-si jamais aparece no fenômeno, de modo que toda conclusão sobre aquela a partir deste deve ser rejeitada. Tanto a concepção dos filósofos como a dos lógicos, acima mencionados, omitem, segundo Nietzsche, "a possibilidade de que essa pintura - aquilo que para nós homens, se chama vida e experiência - gradualmente veio a ser, está em pleno vir-a-ser, e por isso não deve ser considerado uma grandeza fixa, da qual se pudesse tirar ou rejeitar uma conclusão acerca do criador (da razão suficiente)" (MA I/HH I 16, KSA 2.36).

A razão para tanta diferença, tanta distância entre o mundo metafísico e o mundo do vir-a-ser deve-se, segundo o filósofo, ao fato de termos, ao longo de milhares de anos, olhado o mundo sob exigências estéticas, morais e religiosas, por termos submetido esse mundo sob a cega inclinação, a paixão ou o próprio medo, e ainda mais, por termos nos deixado levar pelos maus hábitos do pensamento. É em virtude disso que hoje esse mundo nos parece tão terrível, tão profundo de significado, repleto de alma e cores. Contudo, fomos nós que o colorimos, foi o intelecto humano quem criou o fenômeno, foi ele quem "introduziu nas coisas as suas errôneas concepções fundamentais” (MA I/HH I 16, KSA 2.37). Agora, esse mundo construído, estranho, terrível e variegado se dá conta de que o mundo da experiência e a coisa-em-si lhe são extraordinariamente distintos e separados, que ele acaba por rejeitar a conclusão sobre esta a partir daquele. Em outras palavras, exorta à renúncia de nosso intelecto e de nossa vontade pessoal "de modo a alcançar o essencial tornando-se essencial". Nietzsche ressalta ainda que houve aqueles que buscaram recolher os traços característicos de nosso mundo dos fenômenos, dessa representação de mundo tecida a partir de erros intelectuais e que foi por nós herdada, e, "em vez de apontar o intelecto como culpado, responsabilizaram a essência das coisas como causa desse inquietante caráter efetivo do mundo" (MA I/HH I 16, KSA 2.37).

80 | Cad. Nietzsche, Guarulhos/Porto Seguro, v.40, n.2, p. 74-97, maio/agosto, 2019. 
A ciência contra a metafísica: Nietzsche e o filosofar histórico...

Em última instância, a concepção de metafísica aqui delineada pelo filósofo caracteriza-se como uma grande ficção, um sonho inventado pelo homem enquanto uma necessidade vital a partir da qual pode oferecer um significado infinito à sua existência. Fink ${ }^{7}$ ressalta que a intenção de Nietzsche está em mostrar que, por detrás dos conceitos de coisa, de substância ou da própria liberdade da vontade, se escondem os desejos e as necessidades humanas. Sendo assim, a importância da metafísica estaria diretamente vinculada aos propósitos fundamentais do coração humano através de sua estrutura conceitual, de tal modo que, caso fosse possível desassociá-la deles, ela não passaria de algo vazio, de uma autointerpretação ilusória.

Sob essa perspectiva, a metafísica estaria também relacionada ao romantismo do homem jovem, que aprecia suas explicações porque ela lhe oferece, nas coisas que antes achava desprezível, algo de significativo, dado que lhe oferece um consolo, fazendo com que ele se sinta menos responsável e as coisas lhe pareçam mais interessantes. Contudo, é certo que mais tarde, este mesmo homem jovem se torne desconfiado de toda explicação metafísica, e então compreenda talvez que os mesmos efeitos podem ser obtidos mediante um caminho mais científico. Poderá ele então descobrir que as explicações físicas e históricas podem oferecer aquele mesmo sentimento de irresponsabilidade e até inflamar ainda mais seu interesse pela vida (cf. MA I/HH I 17, KSA 2.38).

Apresentada apenas como um alívio psicológico, a metafísica assemelha-se também àquilo que o filósofo pensa sobre a religião e a arte. "Até hoje nenhuma religião" - escreve Nietzsche - "seja direta ou indiretamente, como dogma ou como alegoria, conteve uma só verdade. Pois foi do medo e da necessidade que cada uma delas nasceu, e por desvios da razão insinuou-se na existência" (MA I/HH I 110, KSA 2.110). Em relação à arte, o filósofo também afirma com pesar que os artistas de todos os tempos acabaram por levar a uma transfiguração

7 Fink, 2003, p. 39.

Cad. Nietzsche, Guarulhos/Porto Seguro, v.40, n.2, p. 74-97, maio/agosto, 2019. 
Mignoni, N. S.

celestial aquelas concepções que hoje reconhecemos como falsas: "glorificaram os erros religiosos e filosóficos da humanidade, e não poderiam fazê-lo sem acreditar na verdade absoluta desses erros" (MA I/HH I 220, KSA 2.180).

Segundo Nietzsche, acredita-se que quanto mais profundo for o pensamento do homem, quanto mais elevada sua autoestima, quanto mais distante ele estiver dos animais, quanto mais ele assemelhar-se ao gênio, mais perto da essência do mundo e de seu conhecimento ele se encontra. Isso ele pensa fazê-lo com as artes e as religiões. Entretanto, isso seria, para o filósofo, apenas uma florescência (Blüte) do mundo, de modo que, mesmo que muitos assim o creiam, não se pode entender melhor a essência do mundo através das artes ou das religiões, uma vez que ela não existe. Foi o erro que tornou o homem profundo e inventivo a ponto de fazer brotar as religiões e as artes. Seria uma incomoda desilusão se alguém nos desvendasse a essência do mundo uma vez que, nas palavras do próprio Nietzsche, "não é o mundo como coisa em si, mas o mundo como representação (como erro) que é tão rico em significado, tão profundo, maravilhoso, portador de felicidade e infelicidade" (MA I/HH I 29, KSA 2.50).

Nesse sentido, quando se tiver inteiramente descrita e explicada a gênese da religião, da arte e da moral, sem que para isso se tenha recorrido à hipótese de intervenções metafísicas no percurso do trajeto, o problema puramente teórico da "coisa-em-si" e do "fenômeno" não fará mais nenhum sentido. Isso porque através da religião, da arte e da moral não tocamos a "essência do mundo em si", visto que através delas ainda permanecemos no domínio da representação, e, portanto, nenhuma "intuição" é capaz de nos levar adiante. Nessa direção, o filósofo lega à fisiologia e a história do desenvolvimento (Entwicklungsgeschichte) dos organismos e dos conceitos, a tarefa de resolver a questão acerca de como é possível que a nossa imagem seja tão distinta da essência inferida do mundo (cf. MA I/HH I, §10, KSA 2.30).

82 | Cad. Nietzsche, Guarulhos/Porto Seguro, v.40, n.2, p. 74-97, maio/agosto, 2019. 
A ciência contra a metafísica: Nietzsche e o filosofar histórico...

Distanciando-se assim da visão estética e romântica de Schopenhauer e Wagner, o filósofo aposta no diálogo entre a história natural e o filosofar histórico como saída para aquilo que denomina de necessidade metafísica. Entendida pelo filósofo como o efeito póstumo ao declínio da religião, a necessidade metafísica é a consequência de estarmos habituados à representação de um outro mundo do qual se sente falta. Sua superação é necessária pelo fato de que tudo aquilo que nos induzia a supor um outro mundo eram na verdade "apenas erros na interpretação de certos processos", ou seja, não passam de "juizos errados do intelecto". Visto que essa necessidade é o resultado e não a origem, ela pode ser extinta na medida em que cessa sua satisfação (cf. Nachlass/FP 6[290], KSA 9.271). Em outras palavras, a necessidade metafísica "não demonstra nada acerca de uma realidade que corresponda a tal necessidade", argumenta o filósofo, "pelo contrário, justamente porque sentimos necessidade, damos ouvidos à voz da vontade e não àquela do intelecto e, prestando atenção a tal voz, somos induzidos ao erro" (Nachlass/FP 19[85], KSA 8.350).

À superação deste erro, o filósofo contrapõe a vinculação entre o filosofar histórico e a ciência natural, compreendida aqui como aquele novo método filosófico capaz de evidenciar que a dualidade proposta pela metafísica não existe. $O$ que existe não é uma contraposição entre o irracional e o racional, entre a vida para o próximo e o egoísmo, ou ainda entre a verdade e o erro, conforme defende a metafísica, mas antes um erro da razão plantado na própria base dessa contraposição. Pois o que se revela com esse novo método é que, a rigor, não há uma ação que seja totalmente altruísta nem tampouco uma contemplação totalmente desinteressada: "ambas são apenas sublimações, em que o elemento básico parece ter se volatilizado e somente se revela à observação mais aguda" (cf. MA I/HH I 1, KSA 2.23-4). Daí resulta a insistência de Nietzsche acerca da necessidade de se estreitar os vínculos entre a filosofia, ciência e história. 
Mignoni, N. S.

Contudo, a simples junção da filosofia com a ciência e a história não garante o êxito deste diálogo, haja vista que, como Nietzsche mesmo reconhece, o próprio espírito científico se encontra maculado pela necessidade metafísica. A Reforma de Lutero seria uma prova disso ao revelar que, em seu século, todos os movimentos de liberdade do espírito ainda se encontravam frágeis e incertos a ponto da ciência não ter conseguido levantar a cabeça. Nesse sentido, o Renascimento inteiro foi apenas uma primavera precoce, visto que no próprio século XIX a metafísica de Schopenhauer provou que o espírito científico ainda não se encontrava forte o bastante. Nessa direção, mesmo que os dogmas cristãos tenham sido eliminados, a concepção de mundo e a percepção do homem cristã e medieval ainda pode celebrar uma ressureição na teoria de Schopenhauer: "Muita ciência ressoa na sua teoria" - escreve Nietzsche - "mas não é a ciência que a domina e sim a velha "necessidade metafísica" (MA I/HH I 26, KSA 2.47).

Por mais que o filósofo estabeleça uma crítica à metafísica de Schopenhauer, ele também reconhece que ela possibilitou um grande e inestimável benefício. Isso porque ela obrigou que se retornasse a formas antigas de ver o mundo e os homens, o que constituiu um ganho muito grande para a história e a justiça: "creio que ninguém hoje conseguiria facilmente, sem ajuda de Schopenhauer, fazer justiça ao cristianismo e a seus parentes asiáticos: o que é impossível, sobretudo partindo do terreno do cristianismo existente" (MA I/HH I 26, KSA 2.47). Somente depois desse êxito da justiça, somente depois de corrigir a concepção histórica que a era do Iluminismo trouxe consigo, que Nietzsche acredita ser possível levar adiante a bandeira do Iluminismo com os nomes de Petrarca, Erasmo e Voltaire.

Entretanto, o filósofo também acredita que, da mesma forma que durante o Iluminismo não se fez justiça à importância da religião, na reação subsequente também não foi o caso, uma vez que se passou a tratar as religiões com amor, paixão e até mesmo atribuindo-lhe a mais profunda compreensão do mundo. A ciência passou a ser 
A ciência contra a metafísica: Nietzsche e o filosofar histórico...

compreendida como a responsável por despir do hábito dogmático para que, de forma mística, pudesse possuir a "verdade". Para os adversários do Iluminismo, as religiões deveriam expressar assim aquela antiquíssima sabedoria, aquela sabedoria "em si", confluindo com o fato de que toda verdadeira ciência moderna teria nos levado em direção a ela e não para longe dela. Desse modo reinaria entre os antigos sábios e seus sucessores uma harmonia e até mesmo uma identidade de opiniões e o progresso dos conhecimentos. Segundo Nietzsche, tal concepção de religião e de ciência é inteiramente errada e, além do mais, ninguém ousaria ser partidário dela em tempos hodiernos, não fosse a eloquência de Schopenhauer tomála sob sua guarda. Uma eloquência altissonante que, somente após uma geração, alcançou seus ouvintes. Assim, da mesma forma que a interpretação moral-religiosa do mundo e dos homens feita por Schopenhauer serviu para a compreensão do cristianismo e de outras religiões, ele também se enganou quanto ao valor da religião para o conhecimento. Isso porque, segundo Nietzsche, as religiões nasceram da necessidade e do medo e somente por desvios da razão puderam insinuar-se na existência. Nenhuma delas conteve uma verdade sequer, motivo pelo qual Schopenhauer teria sido "apenas um discípulo extremamente dócil dos mestres da ciência de seu tempo, que estimavam o romantismo e haviam abjurado o espírito das Luzes" (MA I/HH I 110, KSA 2.110).

Sob essa perspectiva, Nietzsche enfatiza também que, pelo fato de os filósofos muitas vezes filosofarem sob a influência da tradição religiosa ou, pelo menos, sob a antiga e hereditária necessidade metafísica, chegaram a teorias bem parecidas com as teorias religiosas judaicas, cristãs ou indianas. Em virtude disso, acabaram inventando fábulas a respeito da semelhança de família entre as religiões e a ciência. Contudo, é também enfático ao afirmar que "entre a religião e a verdadeira ciência não existe parentesco, nem mesmo amizade ou inimizade: elas habitam planetas diversos" (MA I/HH I 110,KSA 
Mignoni, N. S.

2.111). Disso resulta que, sempre que uma se apresenta sob o olhar da outra, recai sobre ela a suspeita de sua autenticidade, uma vez que "toda filosofia que deixa brilhar, na escuridão de suas últimas perspectivas, uma cauda de cometa religiosa, torna suspeito aquilo que apresenta como ciência: tudo é, presumivelmente, também religião, ainda que sob os enfeites da ciência" (MA I/HH I 110, KSA 2.111). Em A gaia ciência, por exemplo, Nietzsche retomará essa ideia, reafirmando que "na ciência as convicções não têm direito à cidadania" e que somente "quando elas decidem rebaixar-se à modéstia de uma hipótese, de um ponto de vista experimental e provisório, de uma ficção reguladora, pode lhes ser concedida a entrada e até mesmo um certo valor no reino do conhecimento" (FW/ GC 344, KSA 3.574). Contudo, mesmo que a ciência permaneça sob vigilância e suspeita, o que de fato é necessário, permanece o problema da crença, uma vez que não existe ciência sem pressupostos, algo que o próprio filósofo reconhece mesmo afirmando que pressupor uma fé na ciência significa afirmar "um outro mundo que não o da vida, da natureza e da história" (FW/GC 344, KSA 3.577).

Embora a problemática em torno da ciência, presente em $A$ gaia ciência, seja diversa daquela debatida no Humano, demasiado humano, o problema da crença na ciência persiste em ambas. Aqui, no Humano, é visível o esforço de Nietzsche em separar a ciência da religião, na mesma proporção em que separa a ciência da metafísica, da moral ou até mesmo da arte. Sob esse aspecto, o filósofo procura cada vez mais estabelecer o paralelo entre o que de fato pertence à metafísica e o que de verdadeiramente cabe à ciência e à filosofia histórica. Supondo que tenhamos compreendido o viés a partir do qual tanto a religião quanto a metafísica operam, ainda que sem dar a devida importância à arte e a moral, é preciso que passemos ao papel da ciência e da filosofia histórica frente àquele filosofar metafísico. Nesse caso, vale lembrar que não é de todo estranho que o filósofo conceba a ciência aqui como uma espécie de redentora daquele que incansavelmente procura libertar-se das teias metafísicas.

86 | Cad. Nietzsche, Guarulhos/Porto Seguro, v.40, n.2, p. 74-97, maio/agosto, 2019. 
A ciência contra a metafísica: Nietzsche e o filosofar histórico...

Entretanto, para entender melhor o papel da ciência nesse contexto, retornemos ao aforismo que abre essa obra. Nele Nietzsche afirma que, enquanto a filosofia metafísica reinou durante séculos, procurando estabelecer verdades eternas supondo para as coisas uma origem miraculosa provinda diretamente da essência das coisas, a filosofia histórica acabou por constatar que não há opostos, que não há um em si, nem tampouco verdades eternas e que em toda contraposição o que há na verdade não passa de um erro da razão. Essa filosofia histórica, para o filósofo, não pode mais ser concebida como separada da ciência natural e nesse sentido ela configura-se como o mais novo dos métodos filosóficos. Embora a ciência não possa ser confundida com este novo método, ela encontra-se diretamente implicada nele. É na compreensão dessa imbricação que se pode compreender seu papel mais fundamental em relação à metafísica.

No segundo aforismo, Nietzsche ressalta o perigo de conceber verdades eternas, e, nesse caso, referindo-se ao homem quando concebido enquanto uma verdade eterna. Esse seria um defeito hereditário comum entre os filósofos, os quais costumam tomar o homem como uma medida segura das coisas, como se o homem atual, esse mesmo surgido sob a pressão de certas religiões e de certos eventos políticos, fosse a forma fixa da qual se deve partir. A verdade é que tudo o que se declara sobre o homem no fundo "não passa de testemunho sobre o homem de um espaço de tempo bem limitado" (MA I/HH I 2, KSA 2.24). O homem não é algo dado, não é uma aeterna veritas ou uma constante e segura medida das coisas, ele veio a ser, é o resultado de uma contínua mudança, do mesmo modo que não existem fatos eternos e tampouco verdades absolutas. Esta é a razão pela qual o filósofo procura resgatar aqui o sentido histórico, uma vez que através dele se poderia evidenciar a fluidez e o desenvolvimento das coisas, o que evidenciaria, em contraposição à filosofia metafísica, que não apenas o homem é algo que veio a ser, mas inclusive a própria faculdade de cognição, tão cara a esta última. Nessa abordagem, o elemento de destaque recai 
Mignoni, N. S.

sobre o aspecto psicológico do homem contrariando, portanto, toda e qualquer noção de essência ou de natureza humana.

A crítica de Nietzsche chama atenção para o fato de que os filósofos veem instintos (Instinkte) no homem atual e supõe que eles estejam entre os fatos inalteráveis no homem, possibilitando, portanto, uma chave de compreensão do mundo em geral. $\mathrm{O}$ resultado desse erro seria a própria teleologia, a qual se baseia na concepção de que o homem é um ser eterno para o qual, desde o início, todas as coisas se dirigem naturalmente. A questão aqui em jogo é de que não há fatos eternos da mesma forma que não existem verdades absolutas, tudo veio a ser. Essa é a principal razão mediante a qual Nietzsche defende que "o filosofar histórico é doravante necessário, e com ele a virtude da modéstia" (MA I/HH I 2, KSA 2.25).

O filosofar histórico, conforme já citamos anteriormente, é apresentado pelo filósofo como o mais novo método filosófico. Sua maior inovação está em não mais separar, em sua análise, os fenômenos relativos à cultura da história natural. À medida que se distancia dos idealismos com que fora contagiado, sobretudo o romantismo wagneriano, Nietzsche não só abandona concepção cosmológica-metafísica da vida, substituindo-a por uma visão da vida como processo histórico, como também aprofunda ainda mais seus estudos de fisiologia, medicina e ciências naturais. É nesses estudos que o filósofo também se debruça sobre a obra de seu amigo Paul Rée, A Origem dos sentimentos Morais, o qual, sem dúvida, exerceu fortes influências em Humano, demasiado humano. ${ }^{8}$ Nesse

8 A influência de Paul Rée no pensamento nietzschiano, especialmente no período da elaboração de Humano, demasiado humano I é, sem dúvida, profundo. O distanciamento de Nietzsche em relação a Wagner e a Schopenhauer possibilitou ao filósofo ocupar-se ainda mais com as antigas e contínuas aquisições nos âmbitos de sua formação filosófica e filológica, o que lhe garantiu uma singular abertura à modernidade, à história e à ciência. À essa guinada, Rée contribuiu de maneira essencial, e como já evidenciou Paulo D'Iorio (2014, p. 96-97), vários aforismos de Humano, demasiado humano “tecem um verdadeiro diálogo com a filosofia positivista de Paul Rée, um diálogo com pontos de contato e um certo número de divergências não explícitas que se manifestam mais tarde”. Para compreender mais acerca das contribuições de Rée à filosofia de Nietzsche leia-se Rée, Paul. A origem dos sentimentos morais. Tradução de André Itaparica e Clademir Araldi. São Paulo: Editora Unifesp,

88 | Cad. Nietzsche, Guarulhos/Porto Seguro, v.40, n.2, p. 74-97, maio/agosto, 2019. 
A ciência contra a metafísica: Nietzsche e o filosofar histórico...

contexto, Nietzsche passa a dar maior importância à "observação psicológica" enquanto elemento necessário à ciência e, em vista disso, já no aforismo §35 de sua obra, o filósofo trata de suas vantagens:

Que a reflexão sobre o humano, demasiado humano - ou, segundo a expressão mais erudita: a observação psicológica - seja um dos meios que nos permita aliviar o fardo da vida, que o exercício dessa arte proporcione presença de espírito em situações difíceis e distração num ambiente enfadonho, que mesmo das passagens mais espinhosas e desagradáveis de nossa vida possamos colher sentenças, e assim nos sentir um pouco melhor: nisto se acreditava, isto se sabia - em séculos passados (MA I/HH I 35, KSA 2.57).

No aforismo seguinte, o filósofo também tece mais argumentos em favor da observação psicológica e questiona: "não deveríamos estar bastante convencidos das desagradáveis consequências dessa arte, para dela afastar intencionalmente o olhar dos que se educam?" (MA I/HH I 36, KSA 2.58). De um lado, poderíamos reconhecer que de fato uma fé cega na bondade da natureza humana, assim como uma arraigada aversão à dissecação das ações humanas, ou ainda uma espécie de pudor frente à nudez da alma, podem ser mais desejáveis para a felicidade geral de um homem do que o atributo do entranhamento psicológico. Pode ser que a crença no bem, nas ações virtuosas, na abundância de boa vontade impessoal no mundo, tenha tornado os homens melhores à medida em que fez deles menos desconfiados. Por outro lado, "quando imitamos com entusiasmo os heróis de Plutarco", escreve Nietzsche - "e relutamos em indagar suspeitosamente sobre as motivações de seu agir, não é a verdade, mas o bem-estar da sociedade humana que lucra com isso" (MA I/ HH I 36, KSA 2.59).

Nessa perspectiva, Nietzsche aponta para o fato de que, independente dos prós e dos contras, no presente estado de uma

2018 e seu respectivo aparato crítico, bem como o primeiro capítulo da obra de Maria Cristina Fornari, La morale evolitura del gregge: Nietzsche legge Spencer e Mill. Pisa, Edizioni ETS, 2006. 
Mignoni, N. S.

determinada ciência, o ressurgimento da observação moral, que aqui passa a ser entendida também como sinônimo de psicologia, se tornou imprescindível, e a humanidade não pode mais ser poupada da visão cruel da mesa de dissecação psicológica, de suas pinças e bisturis: "Pois aí comanda a ciência que indaga a origem e a história dos chamados sentimentos morais" (MA I/HH I 37, KSA 2.59-60). Tal ciência, ao progredir, tem de expor e resolver os emaranhados problemas sociológicos ignorados em absoluto pela velha filosofia que, com precárias evasivas, sempre fugiu à investigação sobre a origem e a história dos sentimentos morais.

Enfatizando cada vez mais o papel da observação psicológica, Nietzsche afirma que ela estendeu e continua a lançar as mais perigosas armadilhas ao julgamento e ao raciocínio humano, de modo que agora, mais do que nunca, é preciso persistir e manter uma austera valentia a fim de que não nos envergonhemos desse trabalho tão modesto e enfrentemos todo o desdém de que for objeto. É verdade, diz o filósofo, que houve numerosas observações particulares sobre o humano e o demasiado humano. Elas foram primeiramente descobertas e enunciadas em círculos sociais habituados a oferecer sacrifícios, não ao conhecimento científico, mas a uma espirituosa coqueteria. Isso fez com que até mesmo o homem de ciência manifestasse involuntariamente desconfianças ao gênero e à sua seriedade. Entretanto, falta apenas apontar as consequências, pois, como o próprio filósofo afirma: "já se começa a ver que produtos da mais séria natureza crescem no solo da observação psicológica" (MA I/HH I, 37, KSA 2.61).

Nesse ponto, Nietzsche já está plenamente convencido de que a observação psicológica é imprescindível à ciência. Isso porque, ao utilizar-se da observação psicológica juntamente com a filosofia histórica, a ciência poderá confrontar-se com o problema da origem e da história dos sentimentos morais, que desde sempre foram ignorados pela filosofia metafísica e que resultaram em nefastas consequências.

90 | Cad. Nietzsche, Guarulhos/Porto Seguro, v.40, n.2, p. 74-97, maio/agosto, 2019. 
A ciência contra a metafísica: Nietzsche e o filosofar histórico...

Dentre essas consequências, emerge o ponto de partida errôneo a partir do qual muitos filósofos procuraram explicar determinados atos e sentimentos humanos. Segundo o filósofo, fundamentado em uma análise errônea das ações altruístas, por exemplo, constrói-se uma ética falsa que depois, "em favor desta, recorre-se de novo à religião e à barafunda mitológica e que, por fim, às sombras desses turvos espíritos se projetam até mesmo na física e em toda a nossa consideração de mundo" (MA I/HH I 37, KSA 2.60). É em contraposição a essa concepção de mundo que o filósofo procura incorporar a observação psicológica à ciência e à filosofia histórica.

Desse modo, o papel da ciência não estaria na tentativa de adequar a natureza aos conceitos criados, tampouco no trabalho lógico-dedutivo que estabelece leis rígidas e imutáveis àquilo que o filósofo denomina por vir-a-ser, mas, antes, em compreender que a natureza mesma se dá no vir-a-ser, em sua própria transitoriedade e efemeridade. Nisso o filosofar histórico exerce sua função primordial, qual seja, a de evidenciar que a própria história humana não seguiu o mesmo curso, que nem sempre seguiu o mesmo caminho e que nem sempre se desenvolveu sob os mesmos valores. Assim, fazer ciência no sentido nietzschiano é muito mais levar a cabo a perspectiva do jogo, em muito assemelhada à inocência e à aceitação do vir-a-ser da criança zaratustriana do que a da simples e pura necessidade carregada de elementos metafísicos e teleológicos, razão pela qual agora a ciência passa a ser vista enquanto uma continuação da arte. É preciso um alargamento massivo do próprio terreno de pesquisa, uma vez que esse deve ser vivo e estar em processo de vir-a-ser onde a história inteira do homem deve ser consultada. ${ }^{9}$ É por essa razão que o filósofo também evidencia que todo o fardo da cultura, a soma dos sentimentos e conhecimentos e experiências, tornou-se tão grande que há o perigo geral de uma superexcitação de forças nervosas e intelectuais: "Ao cristianismo, aos filósofos, escritores e

9 cf. Montinari, 1965, p. 476-7.

Cad. Nietzsche, Guarulhos/Porto Seguro, v.40, n.2, p. 74-97, maio/agosto, 2019. 
Mignoni, N. S.

músicos devemos uma abundância de sentimentos profundamente excitados" - escreve Nietzsche - "para que eles não nos sufoquem devemos invocar o espírito da ciência, que em geral nos faz um tanto mais frios e céticos, e arrefece a torrente inflamada da fé em verdades finais e definitivas" (MA I/HH I 244, KSA 2.204).

Nisto consiste o papel atribuído à ciência por Nietzsche em Humano, demasiado humano: corrigir e equilibrar os excessos cometidos pela religião, pela filosofia e pela arte. Velar para que o fardo da cultura não se torne demasiado penoso. Esta é a laboriosa e constante tarefa atribuída ao processo da ciência: afastar do homem as nefastas consequências do pensar metafísico. Tal processo deverá celebrar seu maior triunfo numa "história da gênese do pensamento". De uma tal história da gênese do pensamento poderia então resultar que tudo aquilo que agora denominamos de mundo nada mais é do que o resultado de muitos erros e fantasias, os quais surgiram de modo gradual no desenvolvimento dos seres orgânicos. Cresceram entremeados a esses seres orgânicos de tal forma que, ao cabo disso, acabamos por herdá-las como um tesouro acumulado do passado, "como um tesouro: pois o valor de nossa humanidade nele reside" (MA I/HH I 16, KSA 2.37). No entanto, por mais ousada e afirmativa que uma ciência rigorosa assim descrita possa ser, o filósofo é consciente dos limites de seu alcance:

Desse mundo da representação somente em pequena medida a ciência rigorosa pode nos libertar - algo que também não seria desejável -, desde que é incapaz de romper de modo essencial o domínio de hábitos ancestrais de sentimento; mas pode de maneira bastante lenta e gradual iluminar a história da gênese desse mundo como representação - e, ao menos por instantes, nos elevar acima de todo o evento. Talvez reconheçamos então que a coisa em si é digna de uma gargalhada homérica: que ela parecia ser tanto, até mesmo tudo, e na realidade está vazia, vazia de significado (MA I/HH I, 16, KSA 2.37-8).

92 | Cad. Nietzsche, Guarulhos/Porto Seguro, v.40, n.2, p. 74-97, maio/agosto, 2019. 
É através desse processo lento que o filósofo acredita que a ciência pode se tornar o antídoto contra os malefícios da metafísica, da religião e da moral. É por isso que ela precisa do aparato histórico, pois só ele mostra que o mundo é um vir-a-ser, que nele não há nenhuma estabilidade, nenhum noumenon e, portanto, nenhuma metafísica. A história é a grande oposição à metafísica, e é na observação psicológica, no que futuramente se chamará projeto genealógico, que o filósofo espera encontrar elementos essenciais à compreensão da inocência do vir-a-ser, a inocência do próprio mundo e do homem. ${ }^{10}$

Entretanto, uma concepção de mundo e de ciência assim descrita também carrega consigo alguns problemas que o próprio filósofo reconhece. Dentre eles, diz respeito à possibilidade de que, com o passar do tempo, todas as verdades importantes da ciência venham a se tornar cotidianas e comuns, fazendo desaparecer a satisfação. Ao lançar suspeitas sobre a arte, a metafísica e a religião consoladoras, a ciência poderia acabar subtraindo cada vez mais a alegria, empobrecendo, assim, a fonte de prazer a que o homem deve quase que toda sua humanidade. Por conta disso, Nietzsche acredita que uma cultura superior deva dar ao homem um duplo cérebro, uma espécie de cérebro munido de duas câmaras: uma destinada àquilo que é ciência e outra destinada àquilo que não é ciência; ambas devem permanecer uma ao lado da outra sem se confundirem, devem ser estanques e separáveis, uma regulando a outra: "num domínio a fonte de energia, no outro o regulador" - escreve o filósofo - "as ilusões,

10 Note-se que anos mais tarde Nietzsche retomará essa questão da inocência a partir dos discursos de Zaratustra. Ali, mais do que caracterizar o peso exercido pela metafísica e a religião sobre o espírito a ponto de compará-lo a um camelo de carga que avança pelo deserto, ele também elenca o modo como esse camelo deverá transformar-se em leão a fim de abandonar sua carga e usufruir da própria liberdade alcançada em vista de novos valores, agora não mais como um jugo sobre si, mas sob a perspectiva da inocência infantil, da criança que continuamente constrói e destrói, do novo começo, da roda que gira por si mesma, do sagrado dizer sim. "Sim, para o jogo da criação, meus irmãos, é preciso um sagrado dizer-sim: o espírito quer agora a sua vontade, o perdido para o mundo conquista seu mundo" (Za/ZA I, Das três metamorfoses, KSA 4.31). 
Mignoni, N. S.

parcialidades, paixões devem ser usadas para aquecer, e mediante o conhecimento científico deve-se evitar as consequências malignas e perigosas de um superaquecimento" (MA I/HH I 251, KSA 2.209).

No entender de Nietzsche, caso essa exigência não for atendida, o curso posterior do desenvolvimento humano poderá ser previsto quase com certeza: na medida em que o interesse pela verdade acabar, na medida em que ela garantir menos prazer, a ilusão, o erro e a fantasia conquistarão o espaço que antes ocupavam. Assim, a humanidade recairá na barbárie, a ciência em ruínas e, no momento seguinte, igualmente a Penélope, a humanidade voltará a tecer sua tela depois de havê-la desmanchado na noite anterior. Entretanto, frente a este cenário, resta a questão levantada pelo próprio filósofo: "Mas quem garante que ela sempre terá forças para isso?" (MA I/ HH I 251, KSA 2.209).

Diante disso, podemos afirmar que a ciência, tal qual proposta por essa obra, encontra-se diretamente vinculada à postura, a um modo de pensar, ela é educativa, esclarecedora, por isso libertadora. Não é à toa que essa é também a obra dedicada aos espíritos livres. Fazer ciência, segundo Humano, demasiado humano, é vivenciar a postura do espírito livre e vice-versa. Se o espírito livre é aquele que pensa de modo diverso de tudo aquilo que se esperaria com base em sua procedência, então o verdadeiro homem da ciência, o verdadeiro cientista, no sentido mais puro da concepção nietzschiana de ciência, deverá ser um espírito livre. $O$ espírito livre tem por principal característica ser a exceção, pensar de modo diverso daquilo que esperaria em base à sua procedência, sua função ou segundo as opiniões que predominam em seu tempo. Contrário aos espíritos cativos que são a regra, o espírito livre não permanece subjugado à tradição como aqueles, não permanece sob o jugo da moral, da religião, da metafísica, mas antes encontra-se desvinculado dela. É possuidor da liberdade de escolha, da inocência, de tal modo que para ele, assim como o verdadeiro cientista, o mais importante não

94 | Cad. Nietzsche, Guarulhos/Porto Seguro, v.40, n.2, p. 74-97, maio/agosto, 2019. 
é ter opiniões mais corretas, mas sim haver alcançado a liberdade da tradição pois, enquanto ele exige razões, os outros exigem apenas fé (cf. MA I/HH I 225, KSA 2.189-90).

Portanto, mais do que um conceito, a noção de ciência que aqui apresentamos é uma vivência, mas uma vivência que exige razões, que busca a liberdade do espírito, o abandono das verdades absolutas, das verdades eternas, da fixidez das coisas. Como um espírito livre, todo aquele que se lançar pelos caminhos da inocência do vir-a-ser, nos moldes dessa ciência, deverá assemelhar-se não ao andarilho que persegue sua meta, pois essa não existe, mas sim ao errante, àquele que tem olhos abertos para tudo aquilo que realmente sucede no mundo. Deverá ter alegria na mudança e na passagem confiante de que mesmo havendo dias e noites ruins, sempre haverá aquele dia em que sua alma encontra o equilíbrio matutino. Juntamente com aqueles que estão na casa da montanha, na floresta na solidão, ora feliz, ora meditativos, cada um à sua maneira poderá perguntar-se acerca de "como é possível que o dia, entre o décimo e o décimo segundo toque do sino, tenha um semblante assim puro, assim tão luminoso, tão sereno-transfigurado: - eles buscam a filosofia $d a$ manhã" (MA I/HH I 638, KSA 2.363). 
Mignoni, N. S.

\title{
Science against Metaphysics: Nietzsche and the Historical Philosophizing in Human, all to Human
}

\begin{abstract}
With Human, all too human I, Nietzsche established his definitive rupture with Schopenhauer's metaphysics and Wagner's art, while at the same time giving science greater prominence so that, along with historical philosophy, he could serve as the main ally in the struggle against errors and excesses of metaphysics, religion and art, especially the romantic. The present study intends to investigate how Nietzsche relates some characteristics that he sees in the science of his time with his proposal of historical philosophy, which contrasts with traditional metaphysics.
\end{abstract}

Keywords: Nietzsche, Science, History, Metaphysics.

\section{Referências Bibliográficas}

NIETZSCHE, Friedrich W. Digitale Kritische Gesamtausgabe - Digital version of the German critical edition of the complete works of Nietzsche edited by Giorgio Colli and Mazzino Montinari. Disponível em: <http://www.nietzschesource. org/>. Acesso em: 18/10/2018.

. Umano tropo umano: Volume Primo; Frammenti Postumi (1876-1878).

Versioni di Sossio Giametta e Mazzino Montinari. Milano, Adelphi Edizioni S.P.A, 1965.

. Epistolario 1875-1879 (Epistolario di Friedrich Nietzsche, vol. III), a cura di G. Campioni e Federico Gerratana, Adelphi, Milano, 1995.

. Sämtliche Werke. Kritische Studienausgab. G. Colli und M. Montinari (Hg). Berlin: Walter de Gruyter, 1999. 15 Bd.

. Humano Demasiado Humano I: um livro para espíritos livres. Trad. Paulo César de Souza. São Paulo: Companhia das Letras: 2000.

. A Gaia Ciência. Trad. Paulo César de Souza. São Paulo: Companhia das Letras: 2001.

$96 \mid$ Cad. Nietzsche, Guarulhos/Porto Seguro, v.40, n.2, p. 74-97, maio/agosto, 2019. 
A ciência contra a metafísica: Nietzsche e o filosofar histórico...

. Ecce Homo: como alguém se torna o que é. Trad. Paulo César de Souza. São Paulo: Companhia das Letras: 2007.

. Al di là del bene e del male. Nota introdutiva di Giorgio Colli e versione di Ferruccio Masini. Prima edizione digitale. Milano, Adelphi Edizioni S.P.A, 2015.

D'IORIO, Paolo. Nietzsche na Itália: a viagem que mudou os rumos da filosofia. Tradução de Joana Angélica d'Avila Melo. Rio de Janeiro: Zahar, 2014.

FINK, Eugen. Nietzsche’s philosophy. Translated by Goetz Richter. London -New York: Continuum, 2003.

MONTINARI, Mazzino. Che cosa ha detto Nietzsche. A cura e con una Nota di Giuliano Campioni. Adelphi Edizioni: Milano, 1999.

."Umano, troppo Umano" nell'opera di Nietzsche. In: Umano tropo umano: Volume Primo; Frammenti Postumi (1876-1878). Versioni di Sossio Giametta e Mazzino Montinari. Milano, Adelphi Edizioni S.P.A, 1965, p. 475-478.

Recebido em 13/02/2019

Aceito em 25/06/2019 


\section{ERRATA}

No artigo: A ciência contra e metafísica: Nietzsche e o filosofar histórico em Humano, demasiado humano I. Cad. Nietzsche, v. 40, n. 2, p.74-97, 2019. DOI 10.1590/2316-82422019v4002nsm

\section{Na página 74:}

No título, onde se lia:

A ciência contra e metafísica: Nietzsche e o filosofar histórico em Humano, demasiado humano I

\section{Leia-se:}

A ciência contra a metafísica: Nietzsche e o filosofar histórico em Humano, demasiado humano I 